Journal of the American Mosquito Control Association, 24(3):000-000, 2008

Copyright (c) 2008 by The American Mosquito Control Association, Inc.

\title{
FOUR DEGREES OF LATITUDE: MOSQUITO CONTROL ON THE "RIGHT" COASTS OF AUSTRALIA AND FLORIDA, USA?
}

\author{
PAT E. R. DALE, ${ }^{1}$ DOUGLAS B. CARLSON,${ }^{2}$ AND CLIVE S. EASTON ${ }^{3}$
}

\begin{abstract}
This study compares mosquito control within similar environments between 26 and 30 degrees of latitude on the east central coasts of Florida and of Australia. It describes and compares the relevant mosquito-producing environments, the development of mosquito control, legislative framework, funding arrangements, and organizational differences between the areas, including the international interactions that have facilitated good practices. The article identifies some strengths and weaknesses of the programs in each area. Significant strengths include some aspects of funding and administration; collaborations with other organizations; the roles of national and state organizations, including research agencies; and commitment of individuals. Potential weaknesses in programs that are part of larger organizations include their relatively low position in the organizational hierarchy and the need to compete for resources. Programs that are independent districts may lack opportunity to interact with other land management units. Other weaknesses include the relatively high turnover of staff in state environmental resource agencies and the potential loss of institutional memory when long-term mosquito control staff members leave. The case comparison highlights similarities in product use at the individual program level (Indian River Mosquito Control District and Gold Coast Pest Management Unit) and differences in practices including aerial adulticiding being used in Florida but not in Australia.
\end{abstract}

KEY WORDS Subtropical mosquito control, east central Florida, east central Australia, intertidal wetlands

\section{INTRODUCTION}

Between latitudes 26 and 30 are subtropical areas on the central east coasts of both Florida (USA) and Australia that have similar estuarine habitats, development patterns, and need for mosquito control. Since World War II, both have experienced tremendous economic growth, with mosquito control playing an important role in allowing development to occur. These 2 areas, with sophisticated mosquito control programs, were selected to compare and contrast mosquito management in similar climatic zones but on different continents.

In Florida, the area encompasses 9 contiguous mosquito control programs ranging roughly from the city of St. Augustine in the north (St. Johns County, $29^{\circ} 53^{\prime} \mathrm{N}, 81^{\circ} 19^{\prime} \mathrm{W}$ ) to Ft. Lauderdale in the south (Broward County, $26^{\circ} 07^{\prime} \mathrm{N}, 80^{\circ} 08^{\prime} \mathrm{W}$ ) (Fig. 1). The population of this region totals 4.8 million of Florida's total population of 15.98 million. In Australia, the region extends from the north at Noosa $\left(26^{\circ} 28^{\prime} \mathrm{S}, 153^{\circ} 06^{\prime} \mathrm{E}\right)$ in the state of Queensland south to Grafton $\left(29^{\circ} 38^{\prime} \mathrm{S}, 152^{\circ} 58^{\prime} \mathrm{E}\right)$ in the state of New South Wales (NSW) (Fig. 2). The total population is 3.9 million, which is nearly $20 \%$ of the total population of Australia. For this article, the

\footnotetext{
${ }^{1}$ Griffith School of Environment, Griffith University, Nathan, Queensland, Australia 4111.

${ }^{2}$ Indian River Mosquito Control District, P.O. Box 670, Vero Beach, FL 32961-0670.

${ }^{3}$ Health and Environment, Tweed Shire Council, Murwillumbah, New South Wales, Australia 2484.
}

coastal areas will usually be referred to as east central Florida (ECF) and east central Australia (ECA). The following describes the ecological and political environments of ECF and ECA, including major mosquito species and their habitats, their disease-vectoring status, and the methods used to control them. At a more detailed level, 1 program in ECF (Indian River Mosquito Control District [IRMCD]) and another in ECA (Gold Coast Pest Management Unit [GCPMU]) are compared. Finally, factors in each region that make for successful programs as well as those that inhibit achieving goals are identified. This information will help to maximize control success in the future.

\section{ECOLOGICAL OVERVIEW OF THE AREAS}

Climatically both areas are similar, with tropical to temperate conditions: hot summers with summer rainfall maxima, ideal for mosquitoes to rapidly complete their life cycle. The most important physical feature of ECF is the Indian River Lagoon (IRL), a lagoonal estuary extending over $251 \mathrm{~km}$ (157 mi). Semidiurnal tides in the IRL have a mean range of approximately $0.2 \mathrm{~m}(0.6 \mathrm{ft})$, with the annual tidal variation being around $0.8 \mathrm{~m}(2.5 \mathrm{ft})$. In ECA there are extensive intertidal wetlands associated with lowenergy estuarine or protected shorelines. Semidiurnal tides range from approximately 1.0 to $1.8 \mathrm{~m}$ $(3.3-5.11 \mathrm{ft})$ and the annual tidal variation is around $2.5 \mathrm{~m}(8.2 \mathrm{ft})$. 


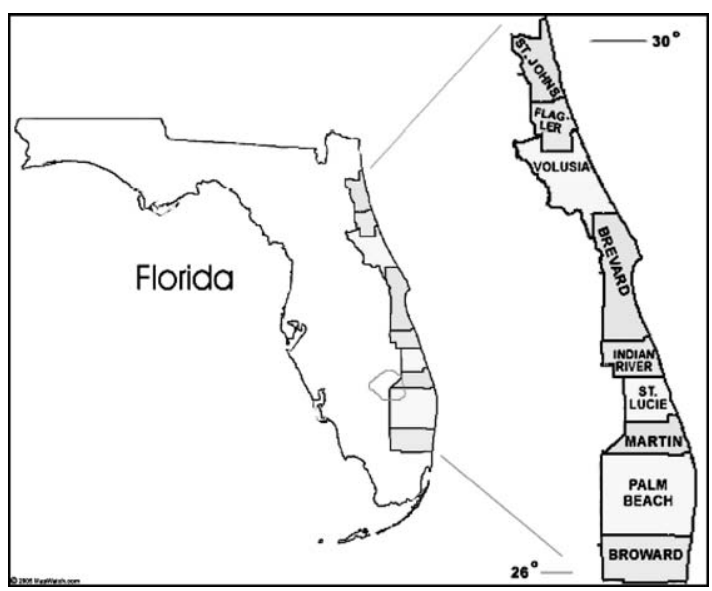

Fig. 1. East central Florida 26-30 degrees of latitude.

Both areas have natural features of ecological significance. The IRL, declared an "Estuary of National Significance" by the U.S. Environmental Protection Agency (EPA), is the most ecologically diverse estuary in the USA and includes over 4,300 species of plants and animals. Additionally 36 species of threatened or endan- gered plants or animals live within the IRL watershed. In ECA, the intertidal salt-marsh and mangrove wetlands have high conservation status and are protected under legislation.

Both areas have extensive mangrove vegetation and salt marsh. In Florida a mosaic of mangroves line the IRL and its islands (Avicennia germinans (Linn.), Rhizophora mangle (Linn.), Laguncularia racemosa Gaertn.). In Australia the mangroves line the coast and estuaries with many of the same genera as in Florida and are dominated by Avicennia marina (Forsk). The intertidal salt marsh is vegetated by halophytes. In Florida these are dominated by the salt grasses (Distichlis spicata (L.)) and the succulents (Salicornia virginica (Linn.) and Batis maritima (Linn.)). In the Australian region salt marshes are vegetated mainly with the grass Sporobolus virginicus (L. Kunth) and succulent Sarcocornia quinqueflora (Bunge ex Ung.-Stern).

\section{Mosquito habitats}

Intertidal habitats: The high salt marshes can produce large populations of salt-marsh mosquitoes. In Florida these include Ochlerotatus taeniorhynchus (Wied.) and Oc. sollicitans (Walk-

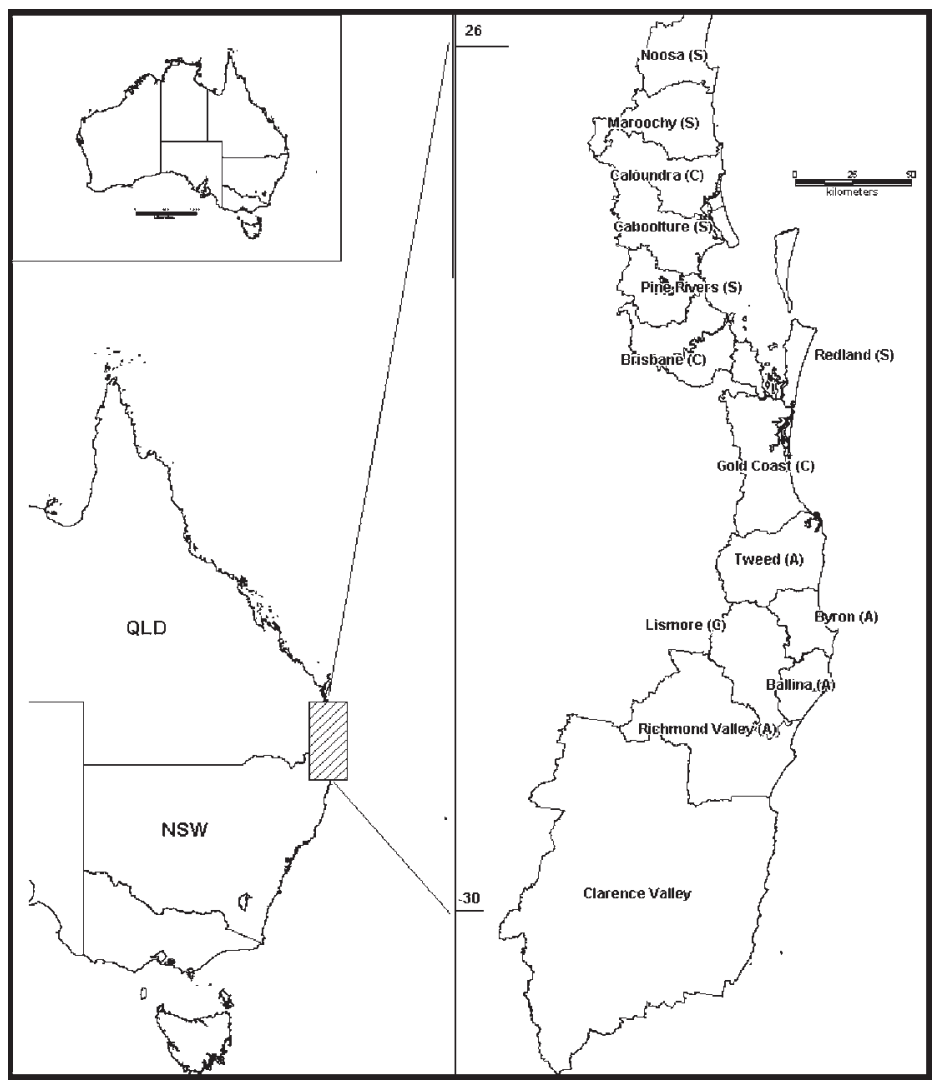

Fig. 2. East central Australia 26-30 degrees of latitude. 
er); in Australia Ae. vigilax (Skuse), is the major pest species.

Other habitats and associated mosquitoes: Other major mosquito-producing habitats within ECF include pastures (Psorophora columbiae (Dyar \& Knab)) and citrus groves (Ps. columbiae and Aedes vexans (Meigen)) (Curtis 1985). Culex nigripalpus (Theobald) are ubiquitous, being produced virtually anywhere standing freshwater occurs (Provost 1969). Containers and tires regularly produce Ae. aegypti (Linn.) and $A e$. albopictus (Skuse). Species whose larvae attach to emergent aquatic plants (e.g., Mansonia spp. and Coquillettidia perturbans (Walker)) also pose a mosquito control problem in many locations (Florida Coordinating Council on Mosquito Control 1998). Invasive exotic vegetation also causes mosquito management problems in the Florida region. Dense stands of Brazilian pepper (Schinus terebinthifolius Raddi) can obstruct access to larval inspection areas and on impoundment dikes. Dense mats of leaf litter from Australian pines (Casuarina spp.) can hinder effective larviciding efforts.

In ECA freshwater mosquito habitats include marshes and swamps (the latter with Melaleuca spp.) and may include some constructed wetlands for storm water and secondary sewage effluent treatment. If not properly designed and effectively maintained, the constructed wetlands have the potential to produce mosquitoes. Of human health importance are $C x$. annulirostris (Skuse) in freshwater environments and particularly in ephemeral pools. Other species of importance include Ae. notoscriptus (Skuse), Ae. procax (Skuse), Verallina funerea (Theobold), CX. sitiens (Wied.), Cq. linealis (Skuse), Cq. variegata (Dobrotworsky), and Ae. multiplex (Theobald).

\section{Mosquito-transmitted diseases}

Both areas include mosquito-borne pathogens with resulting diseases that are typically debilitating rather than fatal. In ECF 2 arbovirusesSt. Louis encephalitis (SLE) and eastern equine encephalomyelitis (EEE) - have historically been endemic. The local vector for SLE is $C x$. nigripalpus with major outbreaks having occurred in the early 1960s, in 1977, and in 1990 . In 1990 there were 223 documented cases of SLE with 11 fatalities (Florida Coordinating Council on Mosquito Control 1998). The hardwood swamp mosquito Culiseta melanura (Coquillett) is a vector of $\mathrm{EEE}$ and the disease occurs in low frequencies, more commonly in the northern half of the region. In 2001, West Nile virus (WNV), locally vectored by Cx. nigripalpus, 1 st entered Florida. Since then, WNV has become the predominant arbovirus but, to date, no major outbreaks have occurred.
In ECA Ross River (RRV) and Barmah Forest viruses (BFV) are the 2 dominant mosquitoborne viruses affecting humans. The main vectors of RRV are Ae. vigilax and $C x$. annulirostris though other species are implicated. Barmah Forest virus has been isolated from Ae. notoscriptus and Ae. procax (Doggett et al. 2005) and both viruses have been isolated from $V e$. funerea (Jeffery et al. 2005). Ross River virus has the highest incidence with around 4,000 cases each year in ECA (Miller et al. 2005). Its ecology is described in Russell (2002).

\section{HISTORICAL OVERVIEW OF THE PROGRAMS}

Mosquito control began in ECF around 1925 with the legislative creation of the Indian River Mosquito Control District. In ECA, mosquito control was initiated in 1959 at the Gold Coast, but it was not until the 1980s that coordination improved to result in effective control across political boundaries. The association between the 2 areas dates back to the late 1970s when links were established between Florida and the Gold Coast (Queensland) to help the Gold Coast mosquito control program.

\section{East central Florida}

There are 9 programs in ECF. Although they were originally created to control salt-marsh mosquitoes, their programs have now broadened to include freshwater mosquito control and arbovirus surveillance.

Modern mosquito control began post-World War II when chlorinated hydrocarbon insecticides initially appeared to be the answer to controlling the tremendous salt-marsh mosquito populations. The appearance of DDT-resistant salt-marsh mosquitoes helped reinforce the realization that effective source reduction needed to play a role in mosquito control here (Patterson 2004). Source reduction in salt-marsh mosquito control dates back to the 1920s when ditching was used. In the 1950 s and 60s, dredging of lagoon bottoms and filling of salt marshes was also used but proved to be too slow and expensive.

In the mid-1950s, the creation of impoundments became the primary source reduction method employed. Over a 15-year period, 192 impoundments were created encompassing approximately 16,700 ha (41,266 acres). Much of that work was accomplished by the individual programs receiving matching funds provided by the Florida Department of Health. Earthen dikes were constructed around known mosquito-producing high salt marsh to create impoundments. This has allowed mosquito control to flood the area with estuarine water to prevent oviposition sites for salt-marsh mosquitoes. Rotational im- 
poundment management (RIM) involves closing culverts and flooding the impoundment during the late spring and summer with the culverts being opened for the remainder of the year (Carlson et al. 1999). Currently approximately 10,927 ha $(27,000$ acres $)$ along the IRL are managed via RIM (Brockmeyer, personal communication).

Over the past half-century in this area, effective ground and aerial larviciding and adulticiding programs have been developed. The fact that mosquito control is necessary on lands owned by many different entities makes the work especially challenging. These properties include large tracts of federally owned refuges and parks, state-owned parks, water management district lands, local county-owned lands, as well as private property.

\section{East central Australia}

In Queensland mosquito control began in 1959 and in northern New South Wales mosquito control began in the early 1980s.

There was little coordinated mosquito control in Queensland until the 1970s. In 1978 the Senior Health Surveyor from the Gold Coast City Council visited the USA, including Florida and Indian River, to examine best practice in an environment similar to ECA. He was particularly impressed with the facilities and the communication between mosquito control staff. His recommendations have guided the development of mosquito control in ECA, leading to programs that include research collaborations between university and mosquito control personnel, exemplified by the innovative source reduction method known as runnelling. Since then there have been numerous visits from both sides and a consistent exchange of ideas and information, including an exchange program for mosquito control professionals, referred to later (Carlson et al. 1999). Increasing collaboration between mosquito control agencies is evidenced by the alliance of local authorities in the $1980 \mathrm{~s}$, as the first Contiguous Local Authority Group (known as CLAG) (Bell and Harris 1987).

To the south in New South Wales, of the 16 local governments in the region, only the Tweed Shire carries out mosquito control directly. It was not until 1980, following community pressure, that mosquito and biting midge control was placed on the Tweed Shire Council agenda. In May 1981, the Council appointed an officer to investigate the mosquito and biting midge problem. Early mosquito-related activities included adult and larval surveys and, in 1983, helicopter application of Abate 5\% sand granules to saltmarsh larval habitats to control Ae. vigilax. During 1984, the Council received a grant to employ 6 long-term unemployed youths for a 6month period in the mosquito unit. This labor was used to carry out some innovative habitat modification works in salt marshes: Hand-dug shallow channels (runnels) were constructed to connect mosquito habitat pools to a common source and to the tidal estuary. This worked to control mosquitoes, with fish visiting via the runnels, so chemical treatment could be terminated. Also, several backwater, poorly flushed mangrove areas had tidal channels dug through them to increase tidal flushing (Easton 1986). A form of open marsh management was also trialled successfully with a 23 ha ( 57 acres) semitidal wetland partially impounded to maintain permanent water levels.

The advantage of close cooperation between contiguous local Councils on biting insect matters was recognized and continues between the Tweed Shire and the Gold Coast City.

\section{GOVERNANCE AND OVERSIGHT}

In both ECF and ECA there are contrasts in funding and governance. In ECF funding may be through independent taxing districts established by an act of the Florida legislature or through a county budget. In ECA all funding comes directly from local government via a general rate on land. In ECF, programs were developed at the discretion of the local communities. In ECA, mosquito control is mandatory in Queensland but is not in New South Wales. As part of the larger local government body in the Australian region biting insect issues can permeate the planning process, resulting in some land use development controls.

\section{East central Florida}

Three programs (Anastasia, East Flagler, Indian River) are independent taxing districts. They have their own elected board of commissioners who annually set a tax rate to fund their programs. The other 6 offices (East Volusia, Brevard, St. Lucie, Martin, Palm Beach, Broward) are divisions of their respective county programs.

Mosquito control programs in Florida are governed by laws originally adopted by the Florida legislature in 1949. Florida Statutes (F.S.) Chapter 388 provides the basic governance, with Rule $5 \mathrm{E}-13$ defining the rules under which the programs must operate. Chapter 388 established the Florida Department of Agriculture and Consumer Services (FDACS) as the regulatory agency that oversees mosquito control programs. Qualifying programs are eligible for state funds. In order to be a state-approved program, FDACS must approve the annual budget and operational plan. Program directors must meet qualifications as defined in 5E-13. Supervisors must obtain Public Health Pest Control certification by which they can supervise up to 15 employees. However, 
many programs require that most employees who apply pesticides obtain this certification. To maintain this certification, 16 continuing education units (CEUs) must be obtained over a 4-year period. All mosquito control pesticides must be registered with the EPA under the Federal Insecticide, Fungicide, Rodenticide Act. Additionally, FDACS must approve each pesticide for use in the state.

The EPA administers a partnership program aimed at reducing pesticide risk called the Pesticide Environmental Stewardship Program (PESP). The American Mosquito Control Association (AMCA) is a "PESP partner" in this program with the Florida Mosquito Control Association (FMCA) and the IRMCD formal participants.

\section{East central Australia}

Within the local government body, mosquito control responsibility usually comes under the Health Department, with its personnel often responsible for a range of other duties, including vermin and restaurants. Mosquito and other biting insect issues are sometimes taken into account in land use planning. In 1993, the Tweed Council's mosquito unit collaborated with Council planning staff to develop Australia's 1st Development Control Plan focusing on mosquitoes and biting midges. This plan outlined local biting insect problems and addressed issues designed to minimize those associated with development. Some local governments now take account of biting insect issues in the development assessment process.

In Queensland mosquito control is carried out by local government. The Public Health Act 2005 defines Public Health Risks in Part 1. Mosquitoes are defined as a "designated pest" and the regulations require that people must ensure that any accumulation of water, whether natural or artificial, is not a breeding ground for mosquitoes (that is, a place where eggs, larvae or pupae are present).

In New South Wales from 1919 to 1993 , state legislation gave powers to councils to carry out mosquito abatement and to control mosquito breeding. In 1993 the State Government introduced a new Local Government Act with very general guidelines (not mandatory), providing for land to be put in a "safe and healthy condition" without specific reference to mosquitoes. The 1993 Act has lost the "teeth" of its predecessor, with enforcement of mosquito orders against landowners sometimes proving to be difficult.

Environmental Health Officers carry out mosquito control for local government. The position normally requires a tertiary qualification or equivalent, and all pesticide applicator personnel are required to be licensed.

\section{INTERACTION WITH REGULATORS}

In both regions mosquito control activities that have the potential to affect natural resources negatively require permits from government agencies. In ECF permits may be required from several agencies, as is the case in New South Wales in ECA. This is not so in Queensland, where applications are usually administered by 1 assessment manager.

\section{East central Florida}

In Florida permits are usually needed for source reduction projects in environmentally sensitive wetlands. Federally, these permits are issued by the U.S. Army Corps of Engineers. At the state level, permits are typically issued by 1 of the state's 5 water management districts. In ECF, funding by 2 water management districts has been instrumental in the improved management of salt-marsh impoundments. Typically the water management district will purchase the necessary water control structures (e.g., pumps, culverts) with the mosquito control office installing, managing, and maintaining it into the future.

Probably the most significant step in interaction between mosquito control and the environmental regulatory community was the Governor's creation of the Florida Coordinating Council on Mosquito Control and its Subcommittee on Managed Marshes in 1983. In 1986, both were formally established in F.S. Chapter 388. These committees, which meet 3-4 times annually, were created to resolve conflicts between mosquito control and environmental resource agencies. Both committees contain members representing mosquito control, environmental agencies, and research institutions. Their existence for more than 20 years has helped create a cooperative atmosphere in seeing that mosquito control goals are met, yet done in an environmentally friendly fashion.

\section{East central Australia}

In both Queensland and New South Wales wetlands are protected by legislation. Activities such as source reduction (usually runnelling) require an environmental impact assessment. In some cases the federal government may be involved, if the Environmental Protection and Biodiversity Conservation Act (1999) is invoked, usually with regard to nationally threatened species or internationally significant wetlands (such as Ramsar sites). In Queensland, mosquito control activities that require permits are administered under the Integrated Planning Act (1997), providing a 1-stop shop for development approvals. This is a recent change and may involve negotiation behind the scenes with relevant state 
agencies, mainly the Queensland Environmental Protection Agency and the Fisheries Department of the Department of Primary Industries. There are no formal interaction mechanisms with the agencies until a formal application is made, though they can provide advice.

In New South Wales, under the Wetlands Act (1985), the State Environmental Planning Policy (SEPP 14) protects coastal tidal and freshwater wetlands. It allows preexisting private land use patterns such as cattle grazing to continue. Many wetlands are prolific mosquito-producing areas, particularly where cattle inhabit. Mosquito control works proposed in classified wetland areas require state government approvals. Any physical works of consequence in these wetlands also requires an environmental impact statement (EIS). Without an equivalent to the Integrated Planning Act of Queensland, approvals may also be required under the Fisheries Management Act (1994), Threatened Species Conservation Act (1995), and Native Vegetation Conservation Act (1997).

\section{ROLE OF LOCAL/REGIONAL GROUPS}

There are no formal local groups in ECF, but there are active organizations such as the Florida Mosquito Control Association (FMCA) and Subcommittee on Managed Marshes, both of which encourage information sharing. These meetings allow mosquito control and natural resource professionals to learn the latest issues and significant technological developments. In contrast, in ECA and especially in Queensland, there are several contiguous local government authorities (CLAGs), 3 of which span the area of this study and include Tweed Shire in New South Wales. They have formal arrangements to optimize mosquito control such as the bulk purchase of chemicals and hiring of aircraft to coordinate aerial treatments. At the national level the Mosquito Control Association of Australia Inc. (MCAA) provides information and training, publishes Mosquito Bites and organizes conferences, to help members keep up to date. In New South Wales, the Northern Rivers Mosquito Focus Group was formed in 2003, following a very high regional incidence of RRV and BFV and a desire by many to review constraints and develop strategies to ensure the comfort of residents adjacent to mosquito habitat. In 2004, the 7 local Northern Rivers Councils and stakeholders from a wide range of interests, both governmental and nongovernmental, formalized the Terms of Reference and mission statement "to formulate and promote a co-ordinated and integrated Government response to mosquito management issues in the Northern Rivers Region."

\section{MOSQUITO CONTROL PROGRAM COMPARISONS}

Table 1 summarizes the mosquito control methods in the 2 areas. The main differences are that ECF has mosquito control in all areas, whereas ECA does not; ECF does aerial adulticiding and ECA does not. Both do aerial and ground larviciding, and some forms of permanent control.

To illustrate the similarities and differences between the 2 areas we compare 2 well-established programs in the following section: IRMCD in ECF and GCPMU in ECA.

\section{Case comparisons: Indian River Mosquito Control District and Gold Coast Pest Management Unit}

Two programs that have been interacting since the 1970s are those at the Indian River in Florida and the Gold Coast in Australia. Table 2 compares their programs in some detail. There are budget differences between the 2 areas. The 2005-2006 IRMCD budget was \$41 per capita and the GCPMU was \$4. The lower amount for GCPMU reflects that, as part of a larger organization (the Gold Coast City Council), considerable costs are absorbed within that structure (such as infrastructure and political leadership: elected representatives on committees). Operations use similar chemicals, except that IRMCD also uses a monomolecular film and oil in its larviciding program. The main operational difference is in the area of adult mosquito control. Indian River MCD does both ground and aerial adulticiding, whereas the Gold Coast PMU only uses ground-based adulticiding when required.

\section{ANCILLARY TOPICS: TRAINING, MARSH MANAGEMENT, AND RESEARCH}

\section{Exchange program}

Because mosquito-producing habitats and problems are similar between East Central Florida and East Central Australia, in an effort to share management and research information, the FMCA and MCAA developed an International Personnel Exchange Program in the early 1990s. Over the next decade, 5 Australians and 2 Floridians participated in the program. Typically the visitor stays with families of mosquito control workers in the host country, spending 2-3 months in a hands-on program, thus learning mosquito control techniques used in the host region. By staying with host families, the participants learn the cultural activities of the region and develop long-lasting intercontinental friendships. Some of the information shared that has benefited participants includes larvicide equipment calibration and application methods, political and environ- 
Table 1. Mosquito control methods in east central Florida and east central Australia.

\begin{tabular}{|c|c|c|c|c|c|c|}
\hline \multirow[b]{2}{*}{ Program } & \multirow{2}{*}{$\begin{array}{l}\text { Size in } \mathrm{km}^{2} \\
\text { (square mi) }\end{array}$} & \multirow{2}{*}{$\begin{array}{l}\text { Permanent } \\
\text { control }^{1}\end{array}$} & \multicolumn{2}{|c|}{ Larviciding } & \multicolumn{2}{|c|}{ Adulticiding $^{2}$} \\
\hline & & & Ground & Aerial & Ground & Aerial \\
\hline \multicolumn{7}{|l|}{$\mathrm{ECF}$} \\
\hline Broward & $3,120(1,205)$ & & $x$ & & $x$ & $x$ \\
\hline Palm Beach & $5,112(1,974)$ & & $x$ & & $\times$ & $x$ \\
\hline Martin & $1,440(556)$ & A & $x$ & $x$ & $\times$ & $x$ \\
\hline St. Lucie & $1,481(572)$ & A & $\times$ & $\times$ & $\times$ & $x$ \\
\hline Indian River (I) & $912(352)$ & $\mathrm{A}, \mathrm{C}$ & $x$ & $\times$ & $\times$ & $x$ \\
\hline Brevard & $2,637(1,018)$ & A & $x$ & $x$ & $x$ & $x$ \\
\hline East Volusia & $2,857(1,103)$ & B & $x$ & $x$ & $\times$ & $\times$ \\
\hline East Flagler (I) & 1,577 (609) & & $x$ & $\times$ & $x$ & $\times$ \\
\hline Anastasia (I) & $1,256(485)$ & $\mathrm{C}$ & $\times$ & & $x$ & \\
\hline \multicolumn{7}{|l|}{ ECA } \\
\hline Noosa & 875 (338) & $\mathrm{R}, \mathrm{O}$ & $x$ & $x$ & $x$ & \\
\hline Maroochy & $1,158(447)$ & $\mathrm{R}$ & $x$ & $x$ & $x$ & \\
\hline Caloundra & $1,107(427)$ & $\mathrm{R}$ & $\times$ & $\times$ & & \\
\hline Caboolture & $1,259(486)$ & $\mathrm{R}$ & $x$ & $x$ & $\times$ & \\
\hline Redcliffe & $37(14)$ & $\mathrm{R}$ & $x$ & $x$ & & \\
\hline Pine Rivers & $771(298)$ & & $\times$ & $x$ & $x$ & \\
\hline Brisbane & $1,367(528)$ & & $\times$ & $x$ & & \\
\hline Redland & $537(207)$ & $\mathrm{R}$ & $\times$ & $\times$ & $\times$ & \\
\hline Logan & $250(97)$ & $\mathrm{O}$ & $x$ & $x$ & & \\
\hline Gold Coast & $1,402(541)$ & $\mathrm{R}$ & $x$ & $x$ & $\times$ & \\
\hline Tweed & $1,309(505)$ & $\mathrm{A}, \mathrm{B}, \mathrm{O}, \mathrm{R}$ & $\times$ & $\times$ & & \\
\hline Byron Bay & 567 (219) & \multicolumn{3}{|c|}{ No control } & & \\
\hline Ballina & 484 (187) & \multicolumn{3}{|c|}{ No control } & & \\
\hline Lismore & $1,290(498)$ & \multicolumn{3}{|c|}{ No control } & & \\
\hline Richmond Valley & $3,051(1,178)$ & \multicolumn{3}{|c|}{ No control } & & \\
\hline Clarence Valley & $11,137(4,300)$ & \multicolumn{3}{|c|}{ No control } & & \\
\hline
\end{tabular}

${ }^{1}$ A, impoundment management; B, salt-marsh rehabilitation; C, waste tire removal; $\mathrm{R}$, runnelling, $\mathrm{O}$, other modification (includes OMWM); I - independent taxing district; others are county programs.

2 Adulticiding: in ECA there has been a recent trend to create barriers to flying adults between mosquito larval habitats and human populations with the use of physical and chemical methods.

mental concerns, adulticiding issues, and arbovirus surveillance methodologies (Carlson et al. 1999).

\section{Marsh management considerations}

Below are activities that transcend mosquito control and contribute to environmental conservation and understanding.

Indian River lagoon marsh restoration efforts ( $E C F$ ): Most of the Indian River Lagoon wetlands that were not impounded were impacted in other ways. In the northern region (Volusia County), many unimpounded wetlands were extensively ditched by hand, dynamite, or draglines. Dragline work in particular left adjacent spoil piles, which later became dominated by exotic vegetation.

Since 1999, the Volusia County MCD and the St. Johns River Water Management District have collaborated to restore marshes to their preimpacted condition. Many of these are marsh islands where low ground bearing pressure tracked equipment is used so as not to impact existing topography or vegetation. Where appropriate, dikes have been removed and ditches filled. When filling ditches, care is taken not to leave isolated areas that might produce salt-marsh mosquitoes (Brockmeyer et al. 1997).

To date, over $23.5 \mathrm{~km}$ (14.7 mi) of dike have been removed, thus enhancing over 215 ha (531 acres) of previously impounded coastal wetland. Other work in progress will remove an additional $7.4 \mathrm{~km}$ (4.6 miles) of dike that will enhance over 88 ha (218 acres) of previously impounded wetland. Approximately 45 ha (110 acres) of dragline-impacted marsh have been restored, with plans for another 53 ha (130 acres) to be improved soon (Brockmeyer, personal communication).

Solving an environmental problem (ECA): Because the role of mosquito control is within local government, there is an opportunity for mosquito control personnel to contribute to a wider area that may be only indirectly associated with mosquitoes. Tweed Shire is an excellent example of this in the area of acid sulfate soils. In 1987, a major fish kill occurred in the Tweed River, leaving hordes of mosquito larvae alive to feed around the rotting carcasses (Easton 1989). Tweed Council's mosquito man- 
Table 2. Comparison between mosquito programs in Indian River Mosquito Control District and Gold Coast Pest Management Unit.

\begin{tabular}{|c|c|c|}
\hline Program components & $\begin{array}{l}\text { Indian River Mosquito Control District } \\
\text { (independent taxing district) }\end{array}$ & $\begin{array}{l}\text { Gold Coast Pest Management Unit } \\
\text { (local government) }\end{array}$ \\
\hline Area within program & $912 \mathrm{~km}^{2}\left(352 \mathrm{mi}^{2}\right)$ & $1,440 \mathrm{~km}^{2}\left(556 \mathrm{mi}^{2}\right)$ \\
\hline Population 2005 & 128,500 & 483,000 \\
\hline $\begin{array}{l}\text { Significant mosquito-producing } \\
\text { features }\end{array}$ & $\begin{array}{l}\text { Indian River Lagoon, citrus groves, } \\
\text { pastures }\end{array}$ & $\begin{array}{l}\text { Southern Moreton Bay, pastures, } \\
\text { freshwater wetlands }\end{array}$ \\
\hline Staff & $\begin{array}{l}3 \text { elected commissioners, } 26 \text { full-time } \\
\text { employees ( } 5 \text { professional staff), } 3 \\
\text { part-time employees }\end{array}$ & $\begin{array}{l}19 \text { full time staff ( } 6 \text { professional } \\
\text { staff) }\end{array}$ \\
\hline 2005-06 budget & $\$ 5.3$ million & $\$ 1.9$ million (\$AUD 2.35 million) \\
\hline Aerial programs & $\begin{array}{l}\text { Larviciding and adulticiding are } \\
\text { contracted }\end{array}$ & Larviciding by contractor \\
\hline \multicolumn{3}{|c|}{ Permanent control } \\
\hline Method & Tire collection/no./year & Salt-marsh habitat modification \\
\hline Type/amount & $\begin{array}{l}\text { Salt-marsh impoundment management/ } \\
\text { rotational impoundment management } \\
=757 \text { ha }(1,870 \text { acres })\end{array}$ & Runnelling/30 ha ( 74 acres) \\
\hline \multicolumn{3}{|c|}{ Ground larviciding } \\
\hline Chemicals used & $\begin{array}{l}\text { Methoprene, Bacillus thuringiensis } \\
\text { israelensis }(\text { Bti), temephos, } \\
\text { monomolecular film, oil }\end{array}$ & Methoprene, Bti, temephos \\
\hline $\begin{array}{l}\text { Average yearly acreage } \\
\quad(2000-2006)\end{array}$ & Approximately 2,428 ha $(6,000$ acres $)$ & 488 ha $(1,205$ acres $)$ \\
\hline \multicolumn{3}{|c|}{ Aerial larviciding } \\
\hline Chemicals used & $\begin{array}{l}\text { Granular materials: methoprene, } B t i \text {, } \\
\text { temephos }\end{array}$ & $\begin{array}{l}\text { Granular materials: methoprene, } \\
B t i \text {, temephos. Liquid } \\
\text { formulations: methoprene, } B t i\end{array}$ \\
\hline $\begin{array}{l}\text { Average yearly acreage } \\
\quad(2000-2006)\end{array}$ & 8,363 ha $(20,665$ acres $)$ & 17,506 ha $(43,257$ acres $)$ \\
\hline \multicolumn{3}{|c|}{ Ground adulticiding } \\
\hline Chemical used & Permethrin & Natural pyrethrum, bioresmethrin \\
\hline $\begin{array}{l}\text { Average yearly acreage } \\
(2000-2006)\end{array}$ & $20,302 \mathrm{~km}(12,689 \mathrm{mi})$ & $5,453 \mathrm{~km}(3,408 \mathrm{mi})$ \\
\hline \multicolumn{3}{|c|}{ Aerial adulticiding } \\
\hline Chemical used & Naled & None \\
\hline $\begin{array}{l}\text { Average yearly acreage } \\
\quad(2000-2006)\end{array}$ & 28,329 ha $(70,000$ acres $)$ & None \\
\hline \multicolumn{3}{|c|}{ Other } \\
\hline $\begin{array}{l}\text { Service requests (2000-2006) } \\
\quad \text { (average per year) }\end{array}$ & 999 & 572 \\
\hline $\begin{array}{l}\text { Educational programs per year } \\
\text { (approximate no.) }\end{array}$ & 6 & 5 \\
\hline
\end{tabular}

ager, in collaboration with other scientists, investigated the cause and discovered that it was the result of a massive discharge of sulfuric acid, flushed from drained lowlands by heavy rain following a prolonged drought. This led to research on acid-sulfate issues, identifying an association between many persistent larval habitats with highly acidic water. Tidal flushing of drains and backwaters has improved the water quality in many of these areas and drastically reduced associated mosquito production (Easton and Marshall 2000).

\section{Research}

In Florida, 2 state-sponsored laboratories support mosquito biology and control research. They are the University of Florida's Florida Medical Entomology Laboratory in Vero Beach, and Florida A\&M University's Public Health, Entomology, Research and Education Center in Panama City. In addition, research pertinent to mosquito control has been undertaken at other research institutions and several mosquito control offices around the state. 
Table 3. Strengths and weaknesses of east central Florida (ECF) and east central Australia (ECA).

\begin{tabular}{|c|c|c|}
\hline Characteristic & Strength & Weakness \\
\hline \multicolumn{3}{|c|}{ Administrative unit } \\
\hline $\begin{array}{l}\text { Program specific to mosquito } \\
\text { management }\end{array}$ & $\begin{array}{l}\text { Allows } 100 \% \text { time/resource allocation to } \\
\text { mosquito management (ECF) }\end{array}$ & $\begin{array}{l}\text { Less inherent interaction with } \\
\text { other units in the government } \\
\text { (ECF) }\end{array}$ \\
\hline $\begin{array}{l}\text { Unit within a local } \\
\text { government }\end{array}$ & $\begin{array}{l}\text { Access to other units of environmental } \\
\text { management within the } 1 \text { organization } \\
\text { (ECF, ECA). Ability to provide other } \\
\text { units with information (ECF, ECA). }\end{array}$ & $\begin{array}{l}\text { Resources may be diverted from } \\
\text { mosquito management to other } \\
\text { functions (ECF, ECA). } \\
\text { Mosquito control may have a } \\
\text { relatively low position in the } \\
\text { administrative hierarchy (ECF, } \\
\text { ECA). }\end{array}$ \\
\hline $\begin{array}{l}\text { Mosquito control is } \\
\text { restricted to the office's } \\
\text { geographic boundaries }\end{array}$ & & $\begin{array}{l}\text { Mosquito problems transcend } \\
\text { administrative boundaries } \\
\text { (ECF, ECA). }\end{array}$ \\
\hline
\end{tabular}

\begin{tabular}{ll}
\hline & Funding \\
\hline Independent taxing districts & All funds go to the mosquito control
\end{tabular}

Independent taxing districts All funds go to the mosquito control

Resources come from a general district $(\mathrm{ECF})$.

levy on property

Mosquito control competes for its resource allocation $(\mathrm{ECF}$, ECA).

Communications with other bodies

Interagency cooperation Contiguous local authority groups provide (local and regional)

Interagency cooperation (with state/federal agencies)

Interaction with research

Professional associations formal associations for knowledge exchange and coordination (ECA).

Florida Coordinating Council on Mosquito Control and Subcommittee on Managed Marshes smooth relationships with environmental agencies (ECF).

Florida Department of Agriculture and Consumer Services certifies local programs and individuals and administers CEUs (ECF). Mosquito control has excellent cooperation with National Wildlife Refuges (ECF).

Mosquito and Arbovirus Research Committee (MARC) provides an effective link between science and management (ECA). Florida Department of Agriculture and Consumer Services provides research funding to the Florida Medical Entomology Laboratory and Public Health Entomology, Research and Education Center (ECF).

Florida Mosquito Control Association and American Mosquito Control Association active: meetings each year, training, publication, legislative advocacy (ECF). Mosquito Control Association of Australia active: meetings, training, publication (ECA).

\section{Programs have no formal} associations with other mosquito control agencies (ECF).

High turnover of environmental agency personnel and loss of institutional memory (ECF, ECA)

MARC relies largely on financial contributions from its members (ECA).

$$
\text { Environmental issues }
$$

Statutory requirements
Queensland's Mosquito Management Code of Practice provides a defense against a charge of causing environmental harm (ECA).
Environmental impact statement requirements may inhibit activities (ECA). Arthropod control plans can restrict mosquito control on state lands (ECF). 
Table 3. Continued.

\begin{tabular}{|c|c|c|}
\hline Characteristic & Strength & Weakness \\
\hline \multicolumn{3}{|c|}{ Operational issues } \\
\hline Operations & $\begin{array}{l}\text { Shared aerial larviciding services allows for } \\
\text { cost and coordination benefits (ECA). } \\
\text { Aerial adulticiding allows for large-area } \\
\text { adult control (ECF). }\end{array}$ & \\
\hline Resources & $\begin{array}{l}\text { Collaborative purchasing of materials, } \\
\text { equipment (ECF, ECA) }\end{array}$ & \\
\hline \multicolumn{3}{|c|}{ Other } \\
\hline Personnel & $\begin{array}{l}\text { Long-term commitment: Most people spend } \\
\text { many years in mosquito control and have } \\
\text { a sense of camaraderie (ECF, ECA) }\end{array}$ & $\begin{array}{l}\text { Career prospects: There can be } \\
\text { limited opportunities for lateral } \\
\text { movement (ECF, ECA) }\end{array}$ \\
\hline
\end{tabular}

In ECA, most of the southeast Queensland local government bodies are also members of the Mosquito and Arbovirus Research Committee. It is funded by state and local government and industry and carries out research specifically to benefit its members (and ultimately mosquito control generally).

\section{CONCLUSIONS: STRENGTHS AND WEAKNESSES}

Table 3 summarizes the strengths and weaknesses of programs in both areas. The greatest strength within mosquito control is also potentially its most severe weakness. The overwhelming strength is in the commitment and sense of camaraderie among mosquito control personnel, which sustains the programs and facilitates interactions with other agencies. However, institutional memory may be lost when these longterm, dedicated staff members leave, unless appropriate measures are taken to preserve this information. In conclusion, over the past halfcentury, there have been tremendous successes in mosquito control between latitudes 26 and 30 on the "right" coasts of both continents, but there are lessons to be learned and room for improvement in both locations.

\section{DEDICATION}

We dedicate this article to the memory of Keith Ferguson (1926-2007), of the Gold Coast Pest Management Unit, as it is now known. Keith was instrumental in forging enduring links with colleagues in Florida and in providing the impetus for the advancement of mosquito control in ECA and guidance to workers in the area, from field operators to researchers.

\section{ACKNOWLEDGMENTS}

We thank the AMCA reviewers for their helpful comments that informed the revision of this article. We also wish to thank the mosquito control personnel in ECF and ECA for providing information and advice about their programs. In particular we thank Dave Allaway and Roy Durre (ECA). In Florida we thank James Clauson (Florida Department of Agriculture and Consumer Services), who shared program information with us. We also thank Roxanne Connelly (Florida Medical Entomology Laboratory, University of Florida) and Deanna Tomerini (Griffith School of Environment, Griffith University), who reviewed the 1 st draft of the article.

\section{REFERENCES CITED}

Bell KM, Harris JD. 1987. Regional mosquito control in south-east Queensland. Unpublished report.

Brockmeyer RE, Rey JR, Virnstein RW, Gilmore RG, Earnest L. 1997. Rehabilitation of impounded estuarine wetlands by hydrologic reconnection to the Indian River Lagoon, Florida (USA). Wetl Ecol Manag 4:93-109.

Carlson DB, O’Bryan PD, Rey JR. 1999. Florida's saltmarsh management issues: 1991-98. J Am Mosq Control Assoc 15:186-193.

Curtis GA. 1985. Habitat selection strategies of mosquitoes inhabiting citrus irrigation furrows. J Am Mosq Control Assoc 1:169-173.

Doggett SL, Russell RC, Clancy J, Haniotis J, Hueston L, Marchetti M, Dwyer DE. 2005. Arbovirus and vector surveillance in New South Wales, 2001-2004. Arbovirus Res Aust 9:101-103.

Easton C. 1986. Saltmarsh mosquito reduction in Tweed Shire using tidal circulation channels. Environ Health Rev Aust 5-9.

Easton C. 1989. The trouble with the Tweed. Fishing World Aust 58-59.

Easton C, Marshall A. 2000. Control of acidic drainwater-breeding mosquitoes in NSW, Australia, by 
installing controlled leakage holes in tidal flap gates. J Am Mosq Control Assoc 16:19-21.

Florida Coordinating Council on Mosquito Control. 1998. The state of the mission as defined by mosquito controllers, regulators and environmental managers. Gainesville: University of Florida. 207 p.

Jeffery JAL, Kay BH, Ryan PA. 2005. Know thine enemy-biology and control of brackish water vectors, particularly Verallina funerea (Theobold), in Maroochy Shire, Queensland. Arbovirus Res Aust 9:153-158.

Miller M, Roche P, Yohannes K, Spencer J, Bartlett M, Brotherton J, Hutchinson J, Kirk M, McDonald A,
Vadjic C. 2005. Australia's notifiable diseases status, 2003 annual report of the National Notifiable Diseases Surveillance System. Commun Dis Intell (Aust) 25:45-47.

Patterson G. 2004. The mosquito wars: a history of mosquito control in Florida. Gainesville: University Press of Florida. $263 \mathrm{p}$.

Provost MW. 1969. The natural history of Culex nigripalpus. In St. Louis encephalitis in Florida. Tallahassee, FL: Florida State Board of Health Monograph Series No. 12. p 46-62.

Russell RC. 2002. Ross River virus: ecology and distribution. Annu Rev Entomol 47:1-31. 